\title{
GENES CODING FOR MELANOMA ANTIGENS RECOGNISED BY CYTOLYTIC T LYMPHOCYTES
}

\author{
CHARLES DE SMET, CHRISTOPHE LURQUIN, ETIENNE DE PLAEN, \\ FRANCIS BRASSEUR, HASSANE ZAROUR, OLIVIER DE BACKER, PIERRE G. COULIE \\ and THIERRY BOON \\ Brussels, Belgium
}

\begin{abstract}
SUMMARY
It is now well established that human melanoma cells express antigens that are recognised by cytolytic $T$ lymphocytes derived from the tumour-bearing patient. The molecular definition of these antigens is progressing at an accelerated pace. The currently characterised melanoma antigens can be classified into three categories: differentiation antigens, antigens encoded by genes that are specifically expressed in tumours, and antigens encoded by mutated genes. Several of these antigens are sufficiently tumour-specific to qualify them as candidate anti-cancer vaccines in melanoma patients.
\end{abstract}

The prospects for cancer immunotherapy are based mainly on the assumption that cancer cells express specific antigens recognised by $\mathrm{T}$ lymphocytes, as these cells have been shown to mediate tumour rejection in animal models. ${ }^{1}$

For human melanoma, it is often possible to obtain autologous anti-tumour cytolytic $\mathrm{T}$ lymphocytes (CTL) by co-cultivating irradiated tumour cells with blood lymphocytes of the tumour-bearing patient. ${ }^{2}$ This procedure is called the Mixed LymphocyteTumour cell Culture (MLTC). Anti-tumour CTL clones with high activity and specificity have been obtained. ${ }^{3,4}$ Detailed analyses of these CTL clones demonstrated that melanoma cells express multiple antigens. ${ }^{4-6}$

Most anti-melanoma CTL are $\mathrm{CD}^{+} \mathrm{T}$ lymphocytes. Antigens recognised by $\mathrm{CD} 8^{+} \mathrm{CTL}$ are small peptides inserted in a groove of the class I Major Histocompatibility Complex molecules, HLA-A, -B or $-\mathrm{C}$ (Fig. 1). The peptides are produced inside the

From: Ludwig Institute for Cancer Research, Brussels branch, and Cellular Genetics Unit, Université Catholique de Louvain, Brussels, Belgium.

Correspondence to: Charles De Smet, Ludwig Institute for Cancer Research, 74 avenue Hippocrate UCL 7479, B-1200 Brussels, Belgium. same cells, mostly by degradation of cellular proteins, and are transported in the endoplasmic reticulum where they combine with the heavy chain of HLA class I molecules. Following association with $\beta_{2}$-microglobulin, the complexes migrate to the cell surface where they can be recognised by the receptor of the CTL.

The first experimental approaches that led to the molecular identification of antigens recognised by anti-tumour CTL were based on the transfection of recombinant DNA libraries. ${ }^{7}$ More recently, we resorted to another genetic approach based on the transient transfection of cDNA libraries into COS cells. ${ }^{8}$ Once the gene coding for a tumour antigen has been identified, the region encoding the antigenic peptide can be narrowed down by transfecting gene fragments. Synthetic peptides can then be tested for recognition by the CTL.

During the last few years we have characterised several genes encoding human melanoma antigens recognised by CTL. The antigens encoded by these genes fall into three categories: differentiation antigens, antigens encoded by genes that are specifically expressed in tumours, and antigens encoded by mutated genes.

\section{MELANOCYTIC DIFFERENTIATION ANTIGENS}

Several groups have cloned from autologous MLTC CTL that lysed not only the stimulator melanoma cells but also allogeneic melanoma cells. ${ }^{9-11}$ Some of these CTL also recognised allogeneic melanocytes, suggesting that the target antigens were expressed not only by melanoma cells but also by normal cells of the melanocytic lineage. ${ }^{12}$

The first melanoma shared antigens that were characterised proved to be encoded by the tyrosinase 


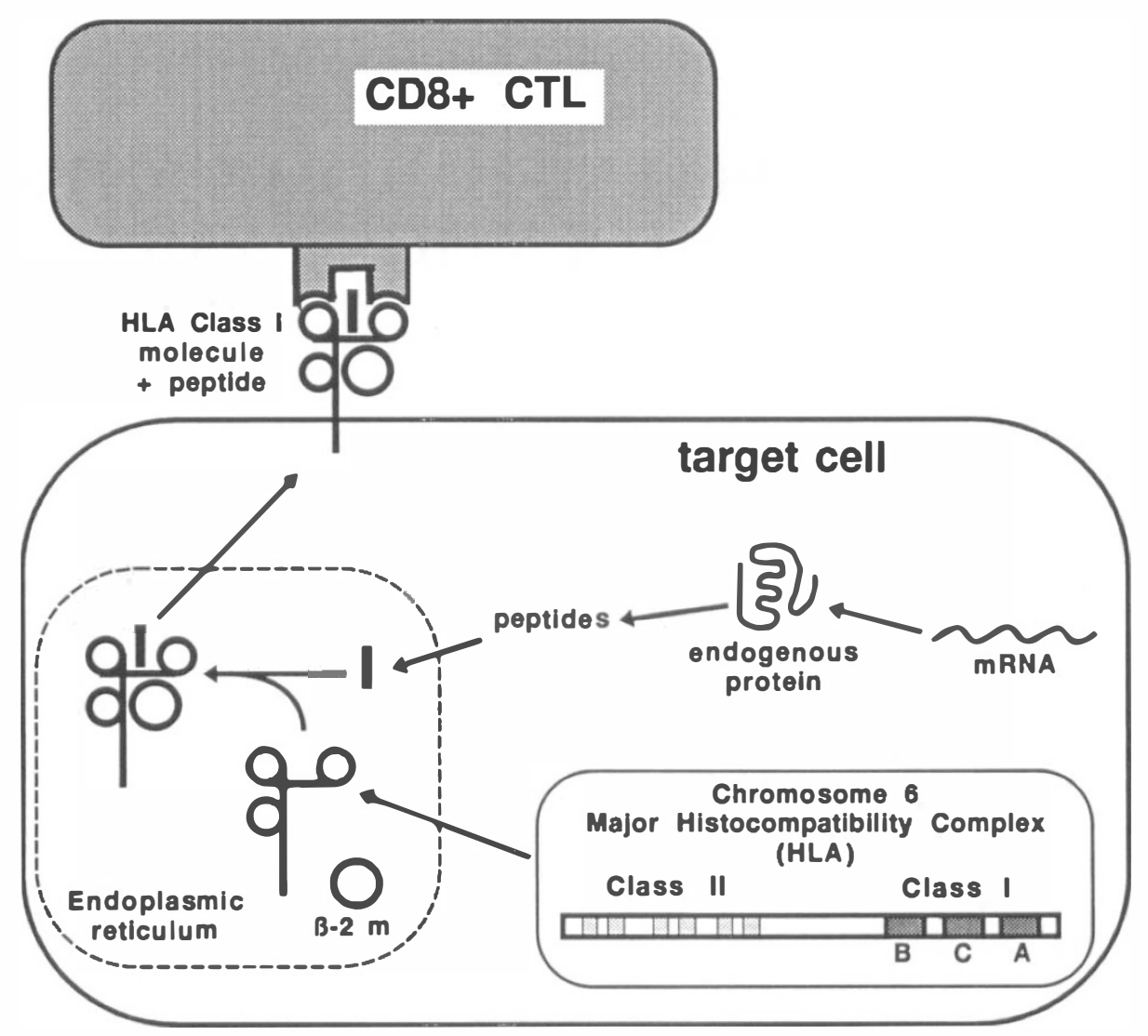

Fig. 1. Mechanism of presentation of an antigen to $C D 8^{+}$cytolytic T lymphocytes. $\beta$ $2 \mathrm{~m}, \beta_{2}$-microglobulin.

gene. ${ }^{13}$ This enzyme converts tyrosine into dihydroxyphenylalanine (DOPA), the precursor of melanin. The tyrosinase gene is expressed in normal melanocytes but not in any other normal tissue. Consistently, tyrosinase is expressed in virtually all melanoma samples, but in no other types of tumours. We have so far identified three antigenic peptides encoded by the tyrosinase gene that are recognised by specific CTL clones: two are presented by HLAA2 class I molecules ${ }^{14}$ and one by HLA-B44. ${ }^{15}$

Another gene was cloned that encodes a shared melanoma antigen presented by HLA-A2. ${ }^{8}$ This new gene presents a pattern of expression similar to that of the tyrosinase gene. Owing to its melanocytic expression, the gene was named Melan-A. Another group identified the same cDNA as coding for an antigen recognised by an HLA-A2-restricted CTL line derived from the lymphocytes infiltrating a melanoma, and named it MART-1. ${ }^{16}$

Pmel17 and gp100 are two melanocyte-specific glycoproteins originating from the same gene via alternative splicing: gp100 contains 641 amino acids, and Pmel17 has an additional stretch of 7 amino acids inserted in position 567. ${ }^{17,18}$ Different groups have identified antigenic peptides derived from the Pmel17/gp100 proteins that are presented at the surface of melanoma cells by HLA-A2 mole- cules. $^{19,20}$ They used either the genetic approach to isolate the cDNA encoding the target antigen, ${ }^{21}$ or a biochemical approach to fish the antigenic peptide eluted from HLA-A2 molecules extracted from melanoma cells. ${ }^{20}$ Interestingly, when we performed a MLTC with tumour cells derived from an HLA-A2 melanoma patient whose tumour expressed high levels of melanocyte-specific genes, the majority of the CTL clones that we obtained (40 of 46) were directed against one of the above-mentioned Pmel17/ gp100 antigens. ${ }^{22}$ This suggests that this antigen can elicit a strong $\mathrm{T}$-cell response.

\section{TUMOUR-SPECIFIC ANTIGENS}

The first human tumour-specific antigen that was identified is antigen MZ2-E, which is expressed by melanoma cell line MZ2-MEL. ${ }^{23}$ The gene encoding this antigen was named $M A G E-1$, for Melanoma $A$ ntiGEn. The sequence of the gene shows no significant identity with known human genes. Gene $M A G E-1$ contains three exons. An open reading frame coding for a protein of 309 amino acids is located in the third exon. Gene $M A G E-1$ is a member of a group of at least 12 closely related genes. $^{24}$ All $M A G E$ genes are located on chromosome $\mathrm{X}$, in Xq28. ${ }^{25}$ More recently, another cluster of 
Table I. Expression of $M A G E, B A G E$ or $G A G E$ genes in tumour samples

\begin{tabular}{lccrc}
\hline & \multicolumn{3}{c}{ \% of positive tumour samples } \\
\cline { 2 - 5 } & MAGE-1 & MAGE-3 & BAGE & GAGE \\
\hline Melanomas & 36 & 64 & 22 & 35 \\
Head and neck carcinoma & 25 & 48 & 7 & 28 \\
Lung (NSCLC) & 36 & 31 & 14 & 30 \\
Bladder carcinomas & 19 & 11 & 10 & 12 \\
Breast carcinomas & 19 & 19 & 0 & 30 \\
Sarcomas & 10 & 15 & 0 & 15 \\
Prostatic carcinomas & 0 & 16 & 0 & 0 \\
Colorectal carcinomas & 0 & 0 & 0 & 0 \\
Renal carcinomas & 0 & 0 & 0 \\
Leukaemias/lymphomas & 0 & & \\
\hline
\end{tabular}

Expression was assessed by PCR amplification of reverse-transcribed RNA extracted from tumour samples frozen immediately after surgery.

$M A G E$-related genes has been identified in Xp21. ${ }^{26}$ Only $M A G E-1$ codes for antigen MZ2-E, which is presented by HLA-A1 class I molecules. ${ }^{27}$ However, another tumour antigen expressed on melanoma cell line MZ2-MEL was later found to be encoded by $M A G E-3{ }^{28}$

The expression of the $M A G E$ genes was evaluated by reverse transcription and PCR amplification of RNA extracted from normal tissues and from tumours. Several sets of primers were chosen that are specific for each $M A G E$ gene. The expression of the $M A G E$ genes was absent in all the normal tissue samples, with the exception of testis and, for $M A G E$ 3 and $M A G E-4$, placenta. ${ }^{24,29}$ The expression of the $M A G E$ genes in testis is probably restricted to the germline cells. ${ }^{30}$ Genes $M A G E-1,-2,-3,-4,-6$ and -12 are also expressed in tumours of different histological types (Table I). Surprisingly, in contrast to cutaneous melanomas, uveal melanomas rarely express $M A G E$ genes. ${ }^{31} M A G E-1,-2$ and -3 were shown to be more often expressed by metastatic melanomas than by primary tumours. ${ }^{32}$

To understand the basis of the tumour-specific expression of the $M A G E$ genes, we have studied the $M A G E-1$ promoter. Three regulatory elements account for most of the $M A G E-1$ promoter activity: one binds to $\mathrm{Sp} 1$ factors, and the two others bind to factors of the Ets family of transcription factors. ${ }^{33}$ The MAGE-1 promoter exhibits transcriptional activity in tumour cell lines that do not express $M A G E-1$, indicating that these cells contain transcription factors capable of inducing $M A G E-1$ promoter activity. One could speculate on the existence of a sequence located outside the $M A G E-1$ promoter, such as a silencer, involved in the cell-specific expression of $M A G E-1$. However, recent data suggest that DNA methylation plays an important role in the regulation of $M A G E-1$ transcription: (i) there is a striking correlation between $M A G E-1$ expression and demethylation of its promoter; (ii) treatment with the demethylating agent azadeoxycytidine activates $M A G E-1$ expres- sion in normal cells and in tumour cell lines that do not express the gene; (iii) the expression of $M A G E-1$ occurs in tumour cell lines showing an important decrease in the overall DNA methylation level. ${ }^{34}$ Taken together, these observations indicate that the expression of $M A G E-1$ in cancer cells is due to the demethylation of the promoter, and that this is a consequence of a genome-wide demethylation process. Genome-wide demethylation is known to occur in tumour cells and to be more pronounced in metastatic $^{35-37}$ than in primary tumours. It is also known to occur in the male germline cells during spermatogenesis. 38,39

Another tumour antigen expressed by melanoma cell line MZ2-MEL was found to be encoded by a new gene, named $B A G E .^{40}$ This gene codes for a putative protein of 43 amino acids and seems to belong to a family of several genes. Like the $M A G E$ genes, $B A G E$ is not expressed in normal tissues except testis, and is expressed in several tumour types (Table I). Yet another MZ2-MEL tumour antigen was characterised, and led to the identification of a new family of genes named $G A G E .^{41}$ Two members of this family encode the antigenic peptide presented by HLA-Cw6. Again, the GAGE genes are silent in normal tissues except testis, and are expressed in different tumour types (Table I).

Antigen NA-17 is recognised on another melanoma by tumour-infiltrating lymphocytes. This antigen was found to be encoded by an abnormal mRNA resulting from the activation of an alternative promoter located in the intron of the $N$-acetylglucosaminyltransferase $\mathrm{V}$ (GnT-V) gene. ${ }^{42}$ Whereas the normal GnT-V mRNA is expressed ubiquitously, the mRNA encoding the NA-17 antigen is not expressed in normal cells but is found, among tumours, in about $50 \%$ of melanomas.

\section{ANTIGENS ENCODED BY MUTATED GENES}

Several years ago, the study of immunogenic variants of mouse tumours obtained by mutagenesis showed 
that point mutation in genes expressed ubiquitously could create antigenic epitopes recognised by CTL. ${ }^{7,43}$

In human melanoma LB33-MEL, an antigen recognised by autologous CTL was found to result from a point mutation in a previously unknown ubiquitously expressed gene. ${ }^{44}$ The mutation was observed only in the melanoma cells of patient LB33. Surprisingly, the mutation is located in an intronic sequence, indicating that the antigenic peptide derives from the translation product of an incompletely spliced mRNA.

Another very interesting example is the point mutation of cyclin-dependent kinase 4 , which produces an antigenic peptide that is presented by HLAA2 class I molecules at the surface of SK29-MEL melanoma cells. ${ }^{45}$ This mutation alters the regulation of the cell cycle, favouring uncontrolled growth of the tumour cells. This is clearly a mutation that is both antigenic and oncogenic. In addition to SK29MEL, 1 of 28 melanomas that were tested carried this mutation.

\section{CONCLUSIONS}

The identification of tumour rejection antigens and the genes encoding the antigenic peptides opens up new possibilities for the active immunisation of cancer patients. The patients liable to benefit from immunisation with a defined antigen can be identified by HLA typing and by assessing the expression of antigen-encoding genes on a tumour sample.

Differentiation antigens are a major cause of concern. The presence of CTL against these antigens reflects a breach in tolerance towards self products. Vitiligo is sometimes associated with melanoma and reported to be of good prognostic value. ${ }^{46} \mathrm{~T}$ cells directed against differentiation antigens may have contributed to the destruction of melanocytes. Postvaccine immunity might be much stronger than spontaneous $\mathrm{T}$ cell responses, and may lead to important adverse effects.

Immunisation of patients against one of the antigens encoded by the $M A G E, B A G E$ or $G A G E$ genes should not cause autoimmune side effects caused by the expression of the relevant gene in the testis. Male germline cells, where expression of these genes appears to be restricted, do not express class I molecules. ${ }^{47}$ Therefore, gene expression should not result in antigen presentation. These conclusions were further strengthened by immunisation studies of male mice against the tumour antigen encoded by mouse gene $P 1 A$, which is also expressed in testis. Immunised male mice showed a strong CTL response and did not show any testicular inflammation (C. Uyttenhove, unpublished results).

Antigens generated by point mutations are expected to be unique for an individual tumour or restricted to a very few. This should make it difficult to develop cancer therapeutic vaccines based on these antigens.

Clinical trials based on some of the tumour antigens that we have mentioned are in progress. ${ }^{48}$ Little is known about efficient modes of immunisation, but it is our hope that responses will be obtained in some patients.

We are particularly grateful to Drs Benoît Van den Eynde, Pierre van der Bruggen and Vincent Brichard for their help in the preparation of this manuscript.

Key words: Melanoma, Tumour antigen, MAGE, Immunotherapy.

\section{REFERENCES}

1. Greenberg PD. Adoptive T cell therapy of tumors: mechanisms operative in the recognition and elimination of tumor cells. Adv Immunol 1991;49:281-355.

2. Boon T, Cerottini J-C, Van den Eynde B, van der Bruggen $\mathrm{P}, \mathrm{Van}$ Pel A. Tumor antigens recognized by T lymphocytes. Annu Rev Immunol 1994;12:337-65.

3. Hérin M, Lemoine C, Weynants P, Vessière F, Van Pel A, Knuth A, et al. Production of stable cytolytic T-cell clones directed against autologous human melanoma. Int J Cancer 1987;39:390-6.

4. Lehmann F, Marchand M, Hainaut P, Pouillart P, Sastre $\mathrm{X}$, Ikeda $\mathrm{H}$, et al. Differences in the antigens recognized by cytolytic $T$ cells on two successive metastases of a melanoma patient are consistent with immune selection. Eur J Immunol 1995;25:340-7.

5. Van den Eynde B, Hainaut P, Hérin M, Knuth A, Lemoine C, Weynants $\mathrm{P}$, et al. Presence on a human melanoma of multiple antigens recognized by autologous CTL. Int J Cancer 1989;44:634-40.

6. Wölfel T, Hauer M, Klehmann E, Brichard V, Ackermann B, Knuth A, et al. Analysis of antigens recognized on human melanoma cells by A2-restricted cytolytic $\mathrm{T}$ lymphocytes (CTL). Int $\mathrm{J}$ Cancer 1993;55:237-44.

7. De Plaen E, Lurquin C, Van Pel A, Mariamé B, Szikora J-P, Wölfel $\mathrm{T}$, et al. Immunogenic (tum ${ }^{-}$) variants of mouse tumor P815: cloning of the gene of tum $^{-}$antigen P91A and identification of the tum mutation. Proc Natl Acad Sci USA 1988;85:2274-8.

8. Coulie PG, Brichard V, Van Pel A, Wölfel T, Schneider J, Traversari C, et al. A new gene coding for a differentiation antigen recognized by autologous cytolytic T lymphocytes on HLA-A2 melanomas. J Exp Med 1994;180:35-42.

9. Anichini A, Fossati G, Parmiani G. Clonal analysis of cytotoxic T-lymphocyte response to autologous human metastatic melanoma. Int J Cancer 1985;36:683-9.

10. Darrow TL, Slingluff CLJ, Seigler HF. The role of HLA class I antigens in recognition of melanoma cells by tumor-specific cytotoxic T lymphocytes: evidence for shared tumor antigens. J Immunol 1989;142: 3329-35.

11. Kawakami Y, Zakut R, Topalian SL, Stötter H, Rosenberg SA. Shared human melanoma antigens: recognition by tumor-infiltrating lymphocytes in HLAA2.1-transfected melanomas. J Immunol 1992;148: 638-43.

12. Anichini A, Maccalli C, Mortarini R, Salvi S, Mazzocchi A, Squarcina P, et al. Melanoma cells and 
normal melanocytes share antigens recognized by HLA-A2-restricted cytotoxic $T$ cell clones from melanoma patients. J Exp Med 1993;177:989-98.

13. Brichard V, Van Pel A, Wölfel T, Wölfel C, De Plaen $\mathrm{E}$, Lethé $\mathrm{B}$, et al. The tyrosinase gene codes for an antigen recognized by autologous cytolytic $\mathrm{T}$ lymphocytes on HLA-A2 melanomas. J Exp Med 1993;178: 489-95.

14. Wölfel T, Van Pel A, Brichard V, Schneider J, Seliger B, Meyer zum Büschenfelde K-H, Boon T. Two tyrosinase nonapeptides recognized on HLA-A2 melanomas by autologous cytolytic T lymphocytes. Eur J Immunol 1994;24:759-64.

15. Brichard VG, Herman J, Van Pel A, Wildmann C, Gaugler B, Wölfel T, et al. A tyrosinase nonapeptide presented by HLA-B44 is recognized on a human melanoma by autologous cytolytic T lymphocytes. Eur J Immunol 1996;26:224-30.

16. Kawakami Y, Eliyahu S, Delgado $\mathrm{CH}$, Robbins PF, Rivoltini L, Topalian SL, et al. Cloning of the gene coding for a shared human melanoma antigen recognized by autologous $T$ cells infiltrating into tumor. Proc Natl Acad Sci USA 1994;91:3515-9.

17. Kwon BS, Chintamaneni C, Kozak CA, Copeland NG, Gilbert DJ, Jenkins N, et al. A melanocyte-specific gene, Pmel 17, maps near the silver coat color locus on mouse chromosome 10 and is a syntenic region on human chromosome 12. Proc Natl Acad Sci USA 1991;88:9228-32.

18. Adema GJ, de Boer AJ, Vogel AM, Loenen WAM, Figdor CG. Molecular characterization of the melanocyte lineage-specific antigen gp100. J Biol Chem 1994;269:20126-33.

19. Kawakami Y, Eliyahu S, Jennings C, Sakaguchi K, Kang X, Southwood S, et al. Recognition of multiple epitopes in the human melanoma antigen gp100 by tumor-infiltrating $\mathrm{T}$ lymphocytes associated with in vivo tumor regression. J Immunol 1995;154:3961-8.

20. Cox AL, Skipper J, Chen Y, Henderson RA, Darrow $\mathrm{TL}$, Shabanowitz J, et al. Identification of a peptide recognized by five melanoma-specific human cytotoxic T cell lines. Science 1994;264:716-9.

21. Kawakami Y, Eliyahu S, Delgado H, Robbins PF, Sakaguchi K, Appella E, et al. Identification of a human melanoma antigen recognized by tumor-infiltrating lymphocytes associated with in vivo tumor rejection. Proc Natl Acad Sci USA 1994;91:6458-62.

22. Zarour H, De Smet C, Léhmann F, Marchand M, Lethé B, Romero $\mathrm{P}$, et al. The majority of autologous cytolytic T-lymphocyte clones derived from peripheral blood lymphocytes of a melanoma patient recognize an antigenic peptide derived from gene Pmel17/gp100. J Invest Dermatol 1996;107:63-7.

23. van der Bruggen $\mathrm{P}$, Traversari $\mathrm{C}$, Chomez $\mathrm{P}$, Lurquin C, De Plaen E, Van den Eynde B, et al. A gene encoding an antigen recognized by cytolytic T lymphocytes on a human melanoma. Science 1991;254:1643-7.

24. De Plaen E, Arden K, Taversari C, Gaforio JJ, Szikora $\mathrm{J}-\mathrm{P}$, De Smet C, et al. Structure, chromosomal localization and expression of twelve genes of the $M A G E$ family. Immunogenetics 1994:40:360-9.

25. Rogner UC, Wilke K, Steck E, Korn B, Poustka A. The melanoma antigen gene $(M A G E)$ family is clustered in the chromosomal band Xq28. Genomics 1995;29:725-31.

26. Muscatelli F, Walker AP, De Plaen E, Stafford AN, Monaco AP. Isolation and characterization of a new $M A G E$ gene family in the $\mathrm{Xp} 21.3$ region. Proc Natl Acad Sci USA 1995;92:4987-91.
27. Traversari $C$, van der Bruggen $P$, Luescher IF, Lurquin C, Chomez P, Van Pel A, et al. A nonapeptide encoded by human gene $M A G E-1$ is recognized on HLA-A1 by cytolytic T lymphocytes directed against tumor antigen MZ2-E. J Exp Med 1992;176:1453-7.

28. Gaugler B, Van den Eynde B, van der Bruggen P, Romero $\mathrm{P}$, Gaforio JJ, De Plaen E, et al. Human gene $M A G E-3$ codes for an antigen recognized on a melanoma by autologous cytolytic $\mathrm{T}$ lymphocytes. J Exp Med 1994;179:921-30.

29. De Smet C, Lurquin C, van der Bruggen P, De Plaen, $\mathrm{E}$, Brasseur $\mathrm{F}$, Boon $\mathrm{T}$. Sequence and expression pattern of the human $M A G E 2$ gene. Immunogenetics 1994;39:121-9.

30. Takahashi K, Shichijo S, Noguchi M, Hirohata M, Itoh $\mathrm{K}$. Identification of MAGE-1 and MAGE-4 proteins in spermatogonia and primary spermatocytes of testis. Cancer Res 1995;55:3478-82.

31. Mulcahy KA, Rimoldi D, Brasseur F, Rodgers S, Liénard D, Marchand $\mathrm{M}$, et al. Infrequent expression of the $M A G E$ gene family in uveal melanomas. Int $\mathbf{J}$ Cancer 1996;66:738-42.

32. Brasseur F, Rimoldi D, Liénard D, Lethé B, Carrel S, Arienti $\mathrm{F}$, et al. Expression of $M A G E$ genes in primary and metastatic cutaneous melanoma. Int $\mathrm{J}$ Cancer 1995;63:375-80.

33. De Smet C, Courtois SJ, Faraoni I, Lurquin C, Szikora J-P, De Backer O, Boon, T. Involvement of two Ets binding sites in the transcriptional activation of the $M A G E 1$ gene. Immunogenetics 1995;42:282-90.

34. De Smet C, De Backer O, Faraoni I, Lurquin C, Brasseur $\mathrm{F}$, Boon $\mathrm{T}$. The activation of human gene $M A G E-1$ in tumor cells is correlated with genome-wide demethylation. Proc Natl Acad Sci USA 1996;93: 7149-53.

35. Gama-Sosa MA, Slagel VA, Trewyn RW, Oxenhandler R, Kuo KC, Gehrke CW, Ehrlich M. The 5methylcytosine content of DNA from human tumors. Nucleic Acids Res 1983;11:6883-94.

36. Bedford MT, van Helden PD. Hypomethylation of DNA in pathological conditions of the human prostate. Cancer Res 1987;47:5274-6.

37. Liteplo RC, Kerbel RS. Reduced levels of DNA 5methylcytosine in metastatic variants of the human melanoma cell line MeWo. Cancer Res 1987;47:2264-7.

38. Rocamora N, Mezquita C. Chicken spermatogenesis is accompanied by a genome-wide loss of DNA methylation. FEBS Lett 1989;247:415-8.

39. del Mazo J, Prantera G, Miguel T, Ferraro M. DNA methylation changes during mouse spermatogenesis. Chromosome Res 1994;2:147-52.

40. Boël P, Wildmann C, Sensi M-L, Brasseur R, Renauld $\mathrm{J}-\mathrm{C}$, Coulie $\mathrm{P}$, et al. $B A G E$, a new gene encoding an antigen recognized on human melanomas by cytolytic T lymphocytes. Immunity 1995;2:167-75.

41. Van den Eynde B, Peeters O, De Backer O, Gaugler B, Lucas S, Boon T. A new family of genes coding for an antigen recognized by autologous cytolytic $T$ lymphocytes on a human melanoma. J Exp Med 1995;182:689-98.

42. Guilloux Y, Lucas S, Brichard VG, Van Pel A, Viret C, De Plaen E, et al. A peptide recognized by human cytolytic $\mathrm{T}$ lymphocytes on HLA-A2 melanomas is encoded by an intron sequence of the $\mathrm{N}$-acetylglucosaminyltranisferase V gene. J Exp Med 1996;183: 1173-83.

43. Lurquin C, Van Pel A, Mariamé B, De Plaen E, Szikora J-P, Janssens C, et al. Structure of the gene coding for $\mathrm{tum}^{-}$transplantation antigen P91A: a 
peptide encoded by the mutated exon is recognized with Ld by cytolytic T cells. Cell 1989;58:293-303.

44. Coulie PG, Lehmann F, Lethé B, Herman J, Lurquin $\mathrm{C}$, Andrawiss M, Boon T. A mutated intron sequence codes for an antigenic peptide recognized by cytolytic T lymphocytes on a human melanoma. Proc Natl Acad Sci USA 1995;92:7976-80.

45. Wölfel T, Hauer M, Schneider J, Serrano M, Wölfel C, Klehmann-Hieb E, et al. A p16 $6^{\mathrm{INK} 4 \mathrm{a}}$-insensitive CDK4 mutant targeted by cytolytic $\mathrm{T}$ lymphocytes in a human melanoma. Science 1995;269:1281-4.
46. Bystryn J-C, Darrell R, Friedman RJ, Kopf A. Prognostic significance of hypopigmentation in malignant melanoma. Arch Dermatol 1987;123: 1053-5.

47. Jassim A, Ollier W, Payne A, Biro A, Oliver RTD, Festenstein $\mathrm{H}$. Analysis of HLA antigens on germ cells in human semen. Eur J Immunol 1989;19:1215-20.

48. Marchand M, Weynants P, Rankin E, Arienti F, Belli $\mathrm{F}$, Parmiani $\mathrm{G}$, et al. Tumor regression responses in melanoma patients treated with a peptide encoded by gene $M A G E-3$. Int J Cancer 1995;63:883-5. 